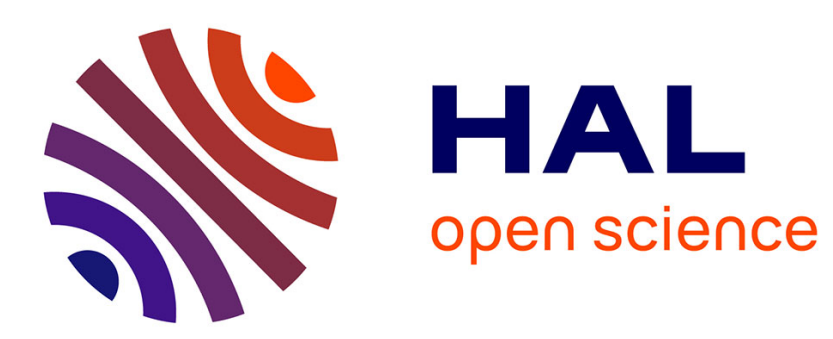

\title{
Application of polystyrene as binder for veneers bonding-the effect of pressing parameters
}

\author{
P. Borysiuk, M. Ł. Mamiński, P. Parzuchowski, A. Zado
}

\section{To cite this version:}

P. Borysiuk, M. Ł. Mamiński, P. Parzuchowski, A. Zado. Application of polystyrene as binder for veneers bonding-the effect of pressing parameters. European Journal of Wood and Wood Products, 2010, 68 (4), pp.487-489. 10.1007/s00107-010-0418-x . hal-00568941

\section{HAL Id: hal-00568941 \\ https://hal.science/hal-00568941}

Submitted on 24 Feb 2011

HAL is a multi-disciplinary open access archive for the deposit and dissemination of scientific research documents, whether they are published or not. The documents may come from teaching and research institutions in France or abroad, or from public or private research centers.
L'archive ouverte pluridisciplinaire HAL, est destinée au dépôt et à la diffusion de documents scientifiques de niveau recherche, publiés ou non, émanant des établissements d'enseignement et de recherche français ou étrangers, des laboratoires publics ou privés. 
EJWWP418_source

\section{Application of polystyrene as binder for veneers bonding}

\section{- the effect of pressing parameters}

P. BORYSIUK ${ }^{\mathrm{a}}(\bowtie)$, M.Ł. MAMIŃSKI ${ }^{\mathrm{a}}$, P. PARZUCHOWSKI ${ }^{\mathrm{b}}$, A. ZADO ${ }^{\mathrm{a}}$

${ }^{a}$ Warsaw University of Life Sciences - SGGW, Faculty of Wood Technology, ul. Nowoursynowska 159, 02-776 Warsaw, Poland

${ }^{b}$ Warsaw University of Technology, Faculty of Chemistry, 3 Noakowskiego St., 00-664 Warsaw, Poland

Email: piotrborysiuk@sggw.pl 
EJWWP418_source

\begin{abstract}
The possibility of veneer bonding with recycled polystyrene was examined. Five pressing regimes were studied. It was shown that low-pressure pre-heating is a necessary step allowing for increasing final shear strength of the woodthermoplastic joints and avoiding indentation of thermoplastic particles to wood.
\end{abstract}

\title{
1 Introduction
}

Many research groups have paid attention to the bonding of wood with thermoplastics which becomes one of the most important directions in wood composites development. This type of material - commonly known as Wood Plastic Composites (WPC) - is mainly manufactured by extrusion process where plasticized mixture of fine wood powder or fibers and thermoplastic are employed (Tangram Techn. 2002, Pritchard 2004, Selke and Wachman 2004). Previous studies by the authors involving typical pressing procedure showed that larger wood particles - chips or veneers could be effectively bonded with thermoplastics (Borysiuk et al. 2006, Hu et al. 2005, Pawlicki and Nicewicz 2002, Youngquist et al. 1994). The main difference between those two approaches is that plasticizing of thermoplastic material occurs only during hot-pressing of the compressed set of veneers. A potential disadvantage of such a procedure is indentation of the tough unplasticized thermoplastic particles to wood and resultant collapse of the pores which become no longer accessible to the binder (thermoplastic). Polystyrene the third most utilized thermoplastic in the world - has a glass transition temperature $(\mathrm{Tg})$ of approximately $90^{\circ} \mathrm{C}$, and below this temperature PS is hard, rigid, and brittle. Bearing in mind the mechanical interlock theory of adhesion, it 
EJWWP418_source

is obvious that the phenomenon can deteriorate the bonding strength of the system. One should also have in mind that boards after pressing should be recooled, because directly after pressing the joint has no satisfying strength. In this paper, the effect of pressing conditions on the bonding strength of waste polystyrene bonded veneers is described.

\section{Materials and methods}

1.5-mm industrial grade pine and birch veneers were used. Waste polystyrene (PS) recovered from disposable plates and utensils was applied as binder. It was determined that possible impurity in waste PS does not influence its properties essentially. The glass transition temperature of waste PS, investigated with the Hoeppler consistometer, was approximately $94^{\circ} \mathrm{C}$.

Triplicate 3-mm thick two-ply pine or birch boards were prepared. Initial experiments showed that the flow temperature of the PS is $180-185^{\circ} \mathrm{C}$. Analysis of heating curves of the set of veneers showed that the temperature of $180 \mathrm{deg}$ inside the bondline was reached within $200 \mathrm{~s}$ (platen temperature $200 \mathrm{deg}$ ). Thus, total pressing time of 300 s is effective to obtain PS flow.

Subsequently, five pressing regimes presented in Fig. 1 were proposed. The bonding parameters were as follows: thermoplastic load - $750 \mathrm{~g} / \mathrm{m} 2$, press temperature $-200^{\circ} \mathrm{C}$, maximum unit pressure $-1.5 \mathrm{MPa}$, total pressing time -300 s. After pressing the boards were re-cooled and conditioned in a climate room (65 $\%, 20{ }^{\circ} \mathrm{C}$ ) for $24 \mathrm{hrs}$. Tensile shear strength of the joints was tested according to EN 205:2005. Wet shear strength was measured after $24 \mathrm{hr}$ water soaking. Twenty samples were tested in each series. 
EJWWP418_source

\section{Figure 1}

\section{Results and discussion}

The results obtained for pressing regimes II, III, and IV (Fig. 2) indicate that initial pre-heating of the assembly at low pressure $(0.15 \mathrm{MPa})$ increased final strength of the joints when compared to pressing regime I where maximum unit pressure as high as $1.50 \mathrm{MPa}$ was applied immediately. In the latter case indentation of the unplasticized polystyrene to the wood and collapse of pores occurred, binder-wood interactions were weakened, and strengths of the joints decreased. The effect is observed both for pine and birch veneers however, for pine it seems to be stronger. Assemblies bonded according regime I with a constant pressure of $1.50 \mathrm{MPa}$ showed - for both species - the lowest bonding strengths which supports the supposition of the authors regarding indentation of PS and reduced contact area. Regimes II-IV including low-pressure pre-heating of the assembly allowing for achieving plastic state to the thermoplastic binder provided a $26-39 \%$ increase in dry shear strengths and $109-143 \%$ increase in wet shear strengths.

\section{Figure 2}

It is worth noting that the differences between strengths obtained for regimes IIIV are statistically insignificant except for dry pine of regime III as well as for wet pine of regime $\mathrm{V}$. 
EJWWP418_source

In general, changes in strengths obtained for pine were smaller than those for birch. The difference comes from the hardness of the species and remains in accordance with the explanation based on indentation of unplasticized polystyrene particles to the wood. Pine veneers being a lot softer, less dense and rougher than birch exhibit higher susceptibility to this process. Moreover, the phenomenon resulted in variation in the bondline thickness.

The strengths obtained for pressing regimes II-IV confirmed the role of lowpressure pre-heating in sufficient plasticizing of the thermoplastic binder.

\section{Conclusion}

It was shown that efficient bonding of wood-thermoplastic system can be achieved only if the thermoplastic binder is sufficiently plasticized to be easily extruded to the pores of the adherend which means that a low-pressure pre-heating step is necessary. Omitting low-pressure pre-heating step and immediate application of work pressure result in lower bonding strengths of the joints. Birch wood having higher hardness occurred to be less indentation-sensitive and subsequently gave higher bonding strengths.

\section{Acknowledgements}

This work was financed by the Polish Department of Education and Science; Project no N 309286933 
EJWWP418_source

\section{References}

Borysiuk P, Pawlicki J, Nicewicz D (2006) New types of raw materials in technologies of wood-based materials. Proceedings of COST Action E44-49 Wood Resources and Panel Properties, Valencia, p. 277-281

EN 205 (2005) Adhesives - Wood adhesives for non-structural applications Determination of tensile shear strength of lap joints

Hu Y, Nakao T, Nakai T, Gu J, Wang F (2005) Vibrational properties of wood plastic plywood. J Wood Sci 51: 13-17

Pawlicki J, Nicewicz D (2002) New Kinds of Wood-Thermoplastics Composites. Proceedings of Workshop: Innovative Materials on the Base of Modified Wood Fiber and Polyolefins, Kassel

Pritchard G (2004) Two technologies merge: wood plastic composites. REINFORCED plastics 6: 26-29

Selke SE, Wachman I (2004) Wood fiber/polyolefin composites. Composites: Part A 35: 321-326

Tangram Technology. Wood-plastic composites a technical review of materials, processes and applications. Tangram technology Ltd. Forest Products Laboratory, Wood-Plastic Composites, Tech line; 2002, COM-1 01/04.

Youngquist JA, Myers GE, Muehl JH, Krzysik AM, Clemons CM (1994) Composites from recycled wood and plastics. Report prepared for US Environmental Protection Agency, Cincinnati 
EJWWP418_source

Fig. 1. Studied pressing regimes

Abb. 1 Untersuchte Pressprogramme

Fig. 2. Shear strengths of the PS-bonded joints (white - dry, grey - wet)

Abb. 2 Trocken- (weiß) und Nass- (grau) Scherfestigkeiten der Verklebungen mit recycliertem Polystyrol 


\section{EJWWP418_source}

I

[MPa] $A$

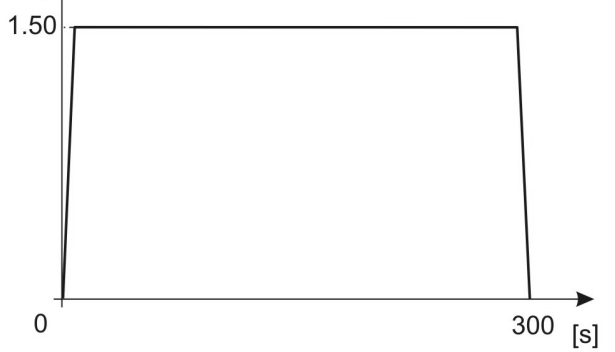

III

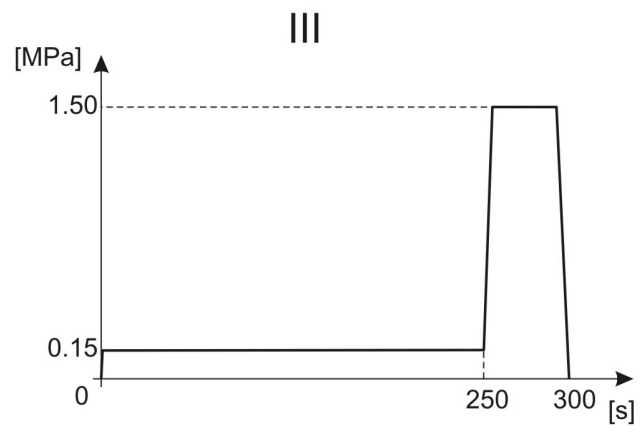

II

[MPa]

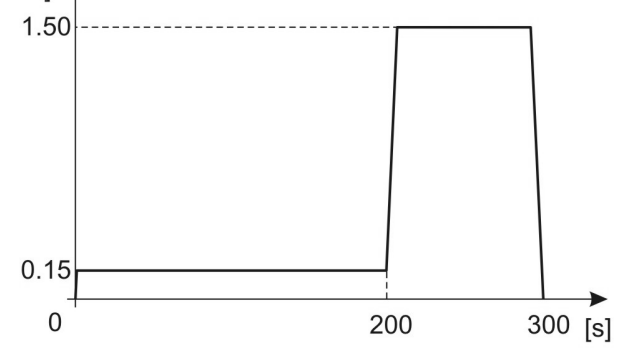

[MPa] A IV

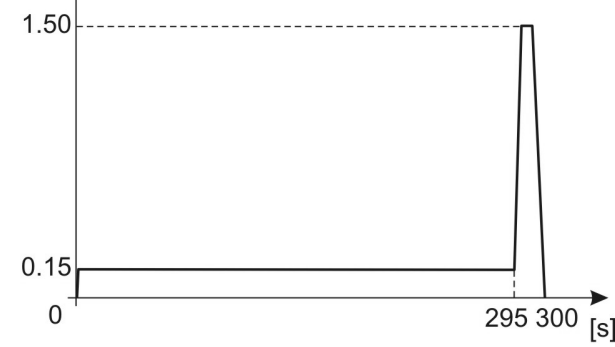

V

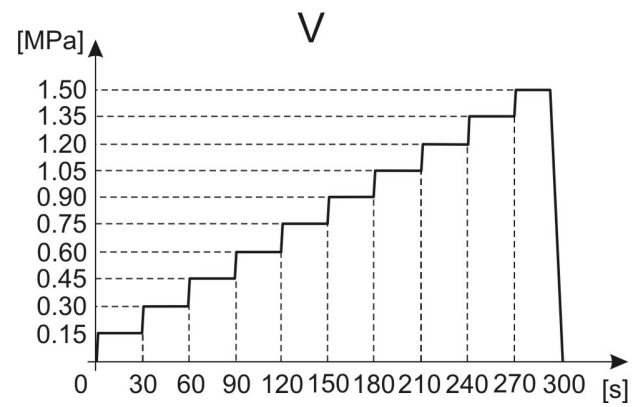


EJWWP418_source
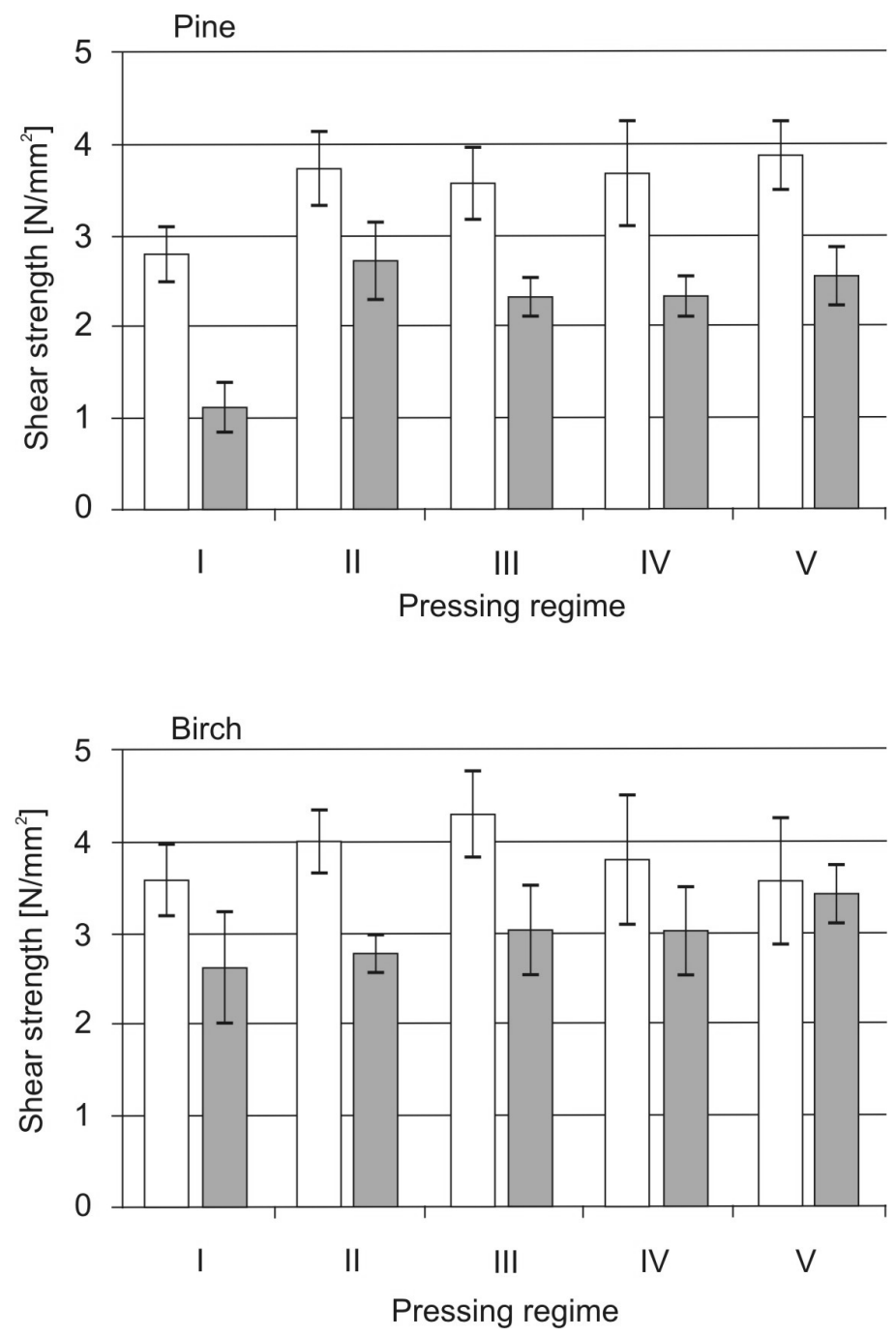